\title{
Quantitative trait loci associated with lodging tolerance in soybean cultivar 'Toyoharuka'
}

\author{
Naoya Yamaguchi*1), Takashi Sayama ${ }^{2)}$, Hiroyuki Yamazaki ${ }^{1,3)}$, Tomoaki Miyoshi ${ }^{1)}$, Masao Ishimoto $^{2)}$ \\ and Hideyuki Funatsuki ${ }^{4)}$ \\ 1) Hokkaido Research Organization Tokachi Agricultural Experiment Station, 2, Minami 9 sen, Shinsei, Memuro, Kasai, Hokkaido 082- \\ 0081, Japan \\ 2) National Institute of Agrobiological Sciences, 2-1-2, Kannondai, Tsukuba, Ibaraki 305-8602, Japan \\ 3) Present address: Hokkaido Research Organization Agricultural Research Department, Higashi 6 sen Kita 15 Gou, Naganuma, Yubari, \\ Hokkaido 069-1395, Japan \\ 4) NARO Western Region Agricultural Research Center, 6-12-1 Nishifukatsu, Fukuyama, Hiroshima 721-8514, Japan
}

Lodging tolerance (LT) is an important trait for high yield and combine-harvesting efficiency in soybean [Glycine $\max$ (L.) Merr.]. Many previous studies have investigated quantitative trait loci (QTLs) for lodging score (LS) in soybean. Most of the investigated QTLs were located in the proximal region of maturity or growth habit loci. The aim of this study was to identify genetic factors for LT not associated with maturity or growth habit. QTL analysis was performed using a recombinant inbred line (RIL) population derived from a cross between 'Toyoharuka' (TH), a lodging-tolerant cultivar, and 'Toyomusume' (TM). The genotypes of TH and TM were estimated as both ele2E3E4 and $d t 1$. The average LS over 4 years was used for QTL analysis, identifying a major and stable QTL, $q L S 19-1$, on chromosome 19. The LS of the near-isogenic line (NIL) with the TH allele at Sat 099, the nearest marker to qLS19-1, was significantly lower than the NIL with the TM allele at that position. The TH allele at Sat_099 rarely had a negative influence on seed yield or other agronomic traits in both NILs and the TM-backcrossed lines. Our results suggest that marker-assisted selection for $q L S 19-1$ is effective for improving LT in breeding programs.

Key Words: soybean, lodging, quantitative trait loci, marker-assisted selection.

\section{Introduction}

Lodging tolerance (LT) is an important trait for high yield and combine-harvesting efficiency in soybean [Glycine max (L.) Merr.]. Numerous studies have investigated the effect of lodging on yield (Noor and Caviness 1980, Saito et al. 2012, Weber and Fehr 1966, Woods and Swearingin 1977). Complete lodging at the seed maturation stage decreases yield by more than $30 \%$ (Saito et al. 2012). Likewise, many studies have investigated the effect of lodging on combineharvesting efficiency (Ono et al. 1990, Uchikawa et al. 2006, Weber and Fehr 1966). Combine-harvesting loss through lodging of soybeans is estimated to be about $20 \%$ (Uchikawa et al. 2006).

Genetic analysis of LT is important in the breeding of lodging-tolerant cultivars. Many studies have investigated quantitative trait loci (QTLs) for lodging score (LS) in soybean (Lee et al. 1996, Mansur et al. 1993, Orf et al. 1999, Specht et al. 2001). However, in these studies, the maturity or growth habit was segregated in the population used for

Communicated by J. Abe

Received May 26, 2014. Accepted August 20, 2014.

*Corresponding author (e-mail: yamaguchi-naoya@hro.or.jp)
QTL analysis. Determinate and indeterminate growth habits are controlled by alleles at the Dt1 locus (Bernard 1972). The stem growth habit influences other agronomic traits: for example, determinate phenotypes generally reach shorter heights and have increased LT than indeterminate phenotypes of similar maturity (Cober and Morrison 2010, Foley et al. 1986). In soybean, several maturity loci are reported to control the time to flowering and maturity. These are designated as $E$ loci (Cober et al. 1996). Recently, the candidate genes E3 and Dt1 were reported to be linked (Liu et al. 2010, Watanabe et al. 2009). Previous studies reported that most QTLs for LS were located in the proximal region of E3 or Dt1 loci (Lee et al. 1996, Mansur et al. 1993, Orf et al. 1999, Specht et al. 2001). Therefore, it is not clear whether genes responsible for these QTLs are closely linked to $E 3$ and $D t 1$ or are pleiotropic.

In this study, we selected a population in which parents reached similar maturity and were determinate for QTL analysis. We performed QTL analysis using recombinant inbred lines (RILs) derived from a cross between the lodging-tolerant cultivar 'Toyoharuka' $(\mathrm{TH})$ and the high lodging cultivar 'Toyomusume' (TM) (Sasaki et al. 1988, Tanaka et al. 2009). Moreover, we developed near-isogenic lines (NILs) from the RIL, and backcrossed (BC) lines using 
the nearest marker to a major QTL to investigate the effect on LT, seed yield, and other agronomic traits. We also investigated the effect of a major QTL in the breeding line Toiku 248 (T248) background by marker-assisted selection (MAS).

\section{Materials and Methods}

\section{Plant materials and field tests}

All cultivars and breeding lines were developed at the Tokachi Agricultural Experiment Station (TAES), Memuro, Hokkaido, Japan. A RIL population (192 lines) was developed by a single seed decent method from a TH $\times$ TM cross (Ikeda et al. 2009, Ohnishi et al. 2011). Both parental cultivars are determinate and reach maturity at similar times (Tanaka et al. 2009). The generation of the RIL population was $\mathrm{F}_{6: 7}$ in 2008, $\mathrm{F}_{6: 8}$ in $2009, \mathrm{~F}_{6: 9}$ in 2011 , and $\mathrm{F}_{6: 10}$ in 2012. Toiku 248, a modern breeding line with high lodging derived from the Toiku $239 \times$ Toiku 238 cross, was used for MAS. Toiku 239 and Toiku 238 have the same origin, TM, in their pedigrees. All field tests were performed in the experimental field of TAES, located at the latitude $42^{\circ} 89^{\prime} \mathrm{N}$. Fertilizer was applied according to Hokkaido fertilization standards $\left(0.2 \mathrm{~N}-1.8 \mathrm{P}_{2} \mathrm{O}_{5}-0.9 \mathrm{~K}_{2} \mathrm{O}-0.4 \mathrm{MgO} \mathrm{kg} \mathrm{a}^{-1}\right)$.

\section{Evaluation of lodging tolerance in the parents}

TH and TM were planted on 22nd May 2008, 18th May 2009, 19th May 2010, and 19th May 2011. Each plot consisted of one (2008), two (2009), or four rows (2010 and 2011), with a length of $1.5 \mathrm{~m}$ (2008 to 2010) or $3.5 \mathrm{~m}$ (2011), spacing of $60 \mathrm{~cm}$, and a plant interval of $6.7 \mathrm{~cm}$; giving a plant population density of 25.0 plants $\mathrm{m}^{-2}$. A randomized complete block design with three replicates was used for the experiments. At the time of maturing, LS was recorded in each plot for LT as: 0 (no lodging) to 4 (completely lodged) (Matsukawa and Banba 1986, Saito et al. 2012). Before harvesting, ten central consecutive plants were selected from each plot for morphological measurement. Main stem length (distance from cotyledonary node to terminal node), number of main stem nodes, and the number of branches (branches with more than two nodes) were recorded for phenotypic evaluation. The TukeyKramer multiple comparison test was used to detect significant differences in agronomic traits among the cultivars. 'Cultivar' and 'year' were considered the two factors.

\section{Evaluation of LT in RILs}

The 192 RILs were planted on 22nd May 2008, 18th May 2009, 18th May 2011, and 22nd May 2012. Each RIL was planted in a plot consisting of $1.5 \mathrm{~m}$ row spaced $60 \mathrm{~cm}$ apart, with a plant interval of 6.7 or $10 \mathrm{~cm}$; giving a plant population density of 25.0 (2008 and 2009) or 16.7 (2011 and 2012) plants $\mathrm{m}^{-2}$. The order of the RILs was randomized in each year to eliminate confounding effects from neighboring RILs. At the time of maturity, LS was recorded in each plot. The average LS over the 4 years was used for QTL analysis. Before harvesting, ten central consecutive plants were selected from each plot for measurement of main stem length. A student's t-test was used to determine significant differences between genotypes.

\section{Calculation of broad-sense heritability for $L S$}

The broad-sense heritability for LS was calculated using data from 2008. The environmental variance was calculated according to the LSs of the parents (three replicates). The phenotypic variance was calculated according to the LSs of the 192 RILs. The genetic variance and broad-sense heritability were calculated as follows: (genetic variance $)=($ phenotypic variance) - (environmental variance); (broad-sense heritability $)=($ genetic variance $) /($ phenotypic variance $)$.

\section{Molecular marker analysis and linkage mapping}

Polymorphic SSR markers were added to the linkage map previously developed by Ikeda et al. (2009) to reconstruct a higher density linkage map. The $\mathrm{F}_{6: 9}$ RIL plants were used for genotyping of the SSR markers. DNA extraction and PCR for the markers were as described previously (Hwang et al. 2009, Sayama et al. 2010). We analyzed the 243 molecular markers using the SSR genotyping panel system (Sayama et al. 2011). In addition to the markers in the panel, six polymorphic SSR markers: BARCSOYSSR 19 1200, BARCSOYSSR_19_1212, BARCSOYSSR_19 1255, BARCSOYSSR_19_1271, BARCSOYSSR_19 1286, and BARCSOYSSR_19_1321 (Song et al. 2010) were also genotyped. These markers are located in the proximal region of a major QTL, qLS19-1. MAPMAKER/EXP 3.0b (Lincoln et al. 1993) was used to determine molecular linkage groups (MLGs) and marker positions. The design of molecular markers for E1,E2,E3,E4 and Dt1 loci was based on previous studies (Liu et al. 2008, 2010, Watanabe et al. 2009, 2011, Xia et al. 2012, Yamanaka et al. 2001, 2005). The genotypes at the $E 1$ to $E 4$ loci of the parental cultivars were estimated as described by Sayama et al. (2010).

\section{QTL analysis}

QTL analysis was performed using QTL Cartographer version 2.5 (Wang et al. 2007). Composite interval mapping (Zeng 1994) was implemented with a threshold logarithm of odds (LOD) score calculated by a permutation test to identify QTLs. The LOD threshold value at the 5\% probability level was calculated using a thousand-replicate permutation test.

\section{Evaluation of LT in NILs}

Near-isogenic lines were developed from a RIL in which the genomic region of interest is segregated, with the other regions being fixed (Ikeda et al. 2009, Tuinstra et al. 1997, Yamanaka et al. 2005). In this study, NILs were developed from the RIL heterozygous at Sat_099, the nearest marker to a major QTL. DNA was extracted from the $\mathrm{F}_{9}$ seeds. The seeds were genotyped at Sat_099, and sorted into TH, TM, and heterozygous genotypes. The $\mathrm{F}_{9}$ progeny of TH and TM genotypes were named as NIL-TH and NIL-TM, respectively. The NILs generations were $F_{10}$ in 2010, and $F_{11}$ in 2011. 
The NILs were planted on 18th May 2011 and 22nd May 2012. Each plot consisted of four rows, with lengths of $1.5 \mathrm{~m} \mathrm{(2010)}$ or $3.5 \mathrm{~m}$ (2011), spaced at $60 \mathrm{~cm}$ with a plant interval of $6.7 \mathrm{~cm}$; giving a plant population density of 25.0 plants $\mathrm{m}^{-2}$. A randomized complete block design with three replicates was used for these experiments. Flowering time was defined as the time at which more than $50 \%$ of plants in the plot were flowering. Maturing time was defined as the time when more than $80 \%$ of plants defoliated and turned yellow, with pods rattling when shaken. At the time of maturing, LS was recorded for each plant. The average LS for each plot was used for statistical analysis. Before harvesting, ten central consecutive plants were selected from each plot for morphological measurement. Main stem length, number of main stem nodes, and the number of branches were recorded for phenotypic evaluation. Mature plants were harvested by hand in each plot. The TukeyKramer multiple comparison test was used for testing significant differences in the agronomic traits among the cultivars and NILs. 'Cultivar' and 'year' were considered the two factors.

\section{Evaluation of $L T$ in backcrossed lines}

The $\mathrm{BC}$ lines were developed as follows: $\mathrm{F}_{1}$ plants from the cross between $\mathrm{TH}$ and TM were obtained, and backcrossed with $\mathrm{TM}$. The $\mathrm{BC}_{1} \mathrm{~F}_{1}$ plants with heterozygous genotypes at Sat_099 were backcrossed with TM. $\mathrm{BC}_{2} \mathrm{~F}_{1}$ plants with heterozygous genotypes at Sat_099 were then selected. The $\mathrm{BC}_{2} \mathrm{~F}_{2}$ plants were genotyped at Sat_099 and sorted into TH, TM, and heterozygous genotypes. The two $\mathrm{BC}_{2} \mathrm{~F}_{3}$ lines with $\mathrm{TH}$ genotypes at Sat_099 were selected from the individual $\mathrm{BC}_{2} \mathrm{~F}_{1}$ plants. These lines were named as TMBC2-1 and TMBC2-2. The $\mathrm{BC}_{2}$ generation was $\mathrm{F}_{4}$ in 2012 and $\mathrm{F}_{5}$ in 2013. The $\mathrm{BC}_{2}$ lines were planted on 5th June 2012 and 21st May 2013. Each plot consisted of two (2012) or four rows (2013) with lengths of $3 \mathrm{~m}$, these were spaced $60 \mathrm{~cm}$ apart with a $20 \mathrm{~cm}$ inter-hill with two plants per hill; giving a plant population density of 16.7 plants $\mathrm{m}^{-2}$. A randomized complete block design with two (2012) or three replicates (2013) was used for these experiments. The measurement methods were as described above in the section 'Evaluation of lodging tolerance in NILs'.

\section{MAS for qLS19-1 in a T248 $\times$ TH background}

$F_{1}$ plants were obtained from a cross between T248 and $\mathrm{TH}$, and $\mathrm{F}_{2}$ plants genotyped at Sat_099 were sorted into T248, TH, and heterozygous genotypes in 2010. All $\mathrm{F}_{2}$ plants with TH (18 plants) or T248 (22 plants) alleles were harvested. Therefore, the $\mathrm{F}_{3}$ lines were developed by MAS. All $40 \mathrm{~F}_{3}$ lines were planted on 19th May 2011. Each plot consisted of a $3 \mathrm{~m}$ row spaced at $60 \mathrm{~cm}$, with a plant interval of $6.7 \mathrm{~cm}$ : giving a plant population density of 25.0 plants $\mathrm{m}^{-2}$. LS was recorded in each plot at the time of maturing. A student's t-test was used to determine significant differences between the genotypes. In 2012, only the $\mathrm{F}_{4}$ lines with TH allele were tested. Eight lines were selected randomly. The eight breeding lines and parental lines were planted on 21st May 2012. Each plot consisted of two rows with lengths of $3.5 \mathrm{~m}$ spaced at $60 \mathrm{~cm}$, with a $20 \mathrm{~cm}$ interhill with two plants per hill; giving a plant population density of 16.7 plants $\mathrm{m}^{-2}$. A randomized complete block design with two replicates was used. LS was recorded in each plot at the time of maturing. Dunnett's test was performed in each agronomic trait using T248 as the reference.

\section{Results}

\section{Evaluation of LT in the parents}

'Toyoharuka' was lodging tolerant while TM displayed high lodging at the flowering to maturing stage (Fig. 1A, 1B). The LS of TH was significantly lower than that of TM, even though the main stem length and the number of main stem nodes were similar (Table 1). The number of branches in TH was significantly less than that of TM (Table 1). The genotypes at the $E 1$ to $E 4$ loci of TH and TM were estimated to be the same, ele2E3E4 (Table 1). The determinate genotypes of both TH and TM were $d t 1$ (Table 1). These results suggested that LT in the RIL population could be evaluated without the effects of the E1,E2,E3,E4 and Dt1 loci.

\section{Broad-sense heritability for $L S$}

The calculated genetic variance and environmental variance for LS were 1.48 and 0.46 , respectively. The broadsense heritability for LS was calculated as 0.76 . These results suggested that LS showed relatively high heritability.

\section{SSR analysis and linkage mapping}

A higher density linkage map was constructed based on available SSR marker locations and their polymorphisms in the parental cultivars (Hwang et al. 2009, Sayama et al. 2011). In all, 177 markers were polymorphic between parents. The resultant genetic linkage map comprised 20 molecular linkage groups (MLGs) and covered $2512 \mathrm{cM}$. The entire genome size was larger than that previously reported by Ikeda et al. (2009).

\section{QTL analysis for LS in RILs}

The LSs of the RILs were evaluated over 4 years because there were no replicates in each year. There were positive correlations between the LSs of the RILs in each pair of years (Table 2). Two-way analysis of variance (ANOVA) was used to test differences among the RILs in LS, with 'RIL' and 'year' as the two factors. The ANOVA revealed that there were significant differences among the RILs $(P<$ 0.001 ). Therefore, we considered years as replicates, and the average LS over 4 years was used for the QTL analysis.

The average LSs over 4 years for TH and TM were 0.8 and 2.7, respectively (Fig. 2). In the RIL population, average LSs varied from 0.0 to 3.7 , and normally distributed (Fig. 2). QTL analysis using the average LS over 4 years was then performed using the 192 RILs. The LOD threshold value at the $5 \%$ probability level was 3.5 . Two QTLs, 

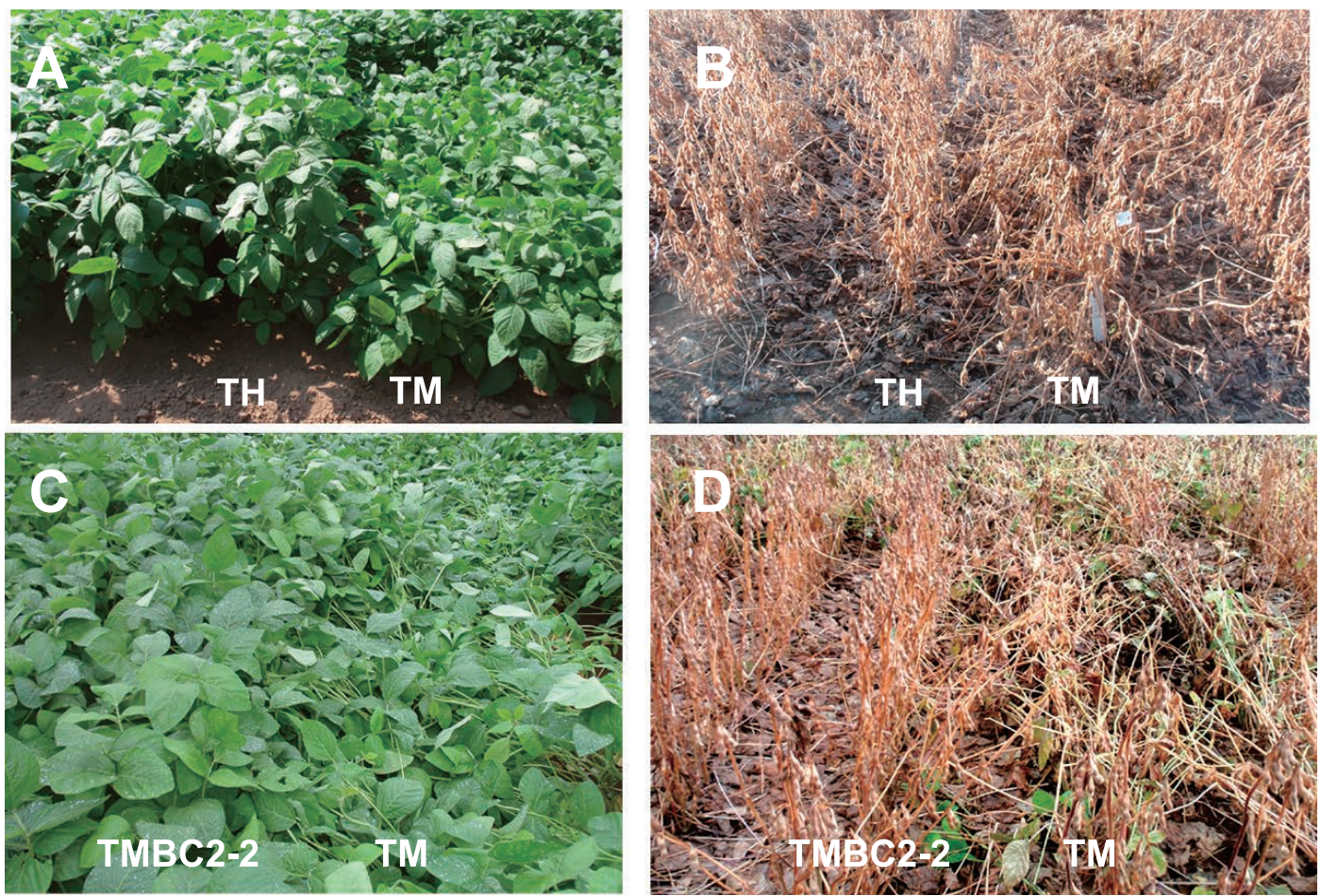

Fig. 1. Representative plants in the field. (A) Shape of the Toyoharuka (TH) and Toyomusume (TM) plants used to create RILs. The photograph was taken on 28th July 2011. (B) TH and TM at harvesting time. The photograph was taken on 5th October 2011. (C) TMBC2-2, a backcrossed line containing the TH genotype at Sat_099, and TM. The photograph was taken on 7th August 2012. (D) TMBC2-2 and TM at harvesting time. The photograph was taken on 12th October 2012.

Table 1. Agronomic traits of the parents (25.0 plants $\mathrm{m}^{-2}$; average in 2008 to 2011)

\begin{tabular}{|c|c|c|c|c|c|c|}
\hline \multirow{2}{*}{ Cultivar } & \multirow{2}{*}{ Lodging score ${ }^{a}$} & \multirow{2}{*}{$\begin{array}{l}\text { Main stem length } \\
(\mathrm{cm})\end{array}$} & \multirow{2}{*}{$\begin{array}{l}\text { No. of main } \\
\text { stem nodes }\end{array}$} & \multirow{2}{*}{$\begin{array}{l}\text { No. of branches } \\
\qquad\left(\mathrm{m}^{-2}\right)\end{array}$} & \multicolumn{2}{|c|}{ Genotype } \\
\hline & & & & & $E$ loci & Determinate \\
\hline TH & 0.7 & 67 & 9.9 & 18.8 & ele2E3E4 & $d t 1$ \\
\hline $\mathrm{TM}$ & $\begin{array}{l}2.2 \\
* *\end{array}$ & $\begin{array}{l}68 \\
\mathrm{~ns}^{b}\end{array}$ & $\begin{array}{c}9.9 \\
\text { ns }\end{array}$ & $\begin{array}{c}53.6 \\
* *\end{array}$ & ele2E3E4 & $d t 1$ \\
\hline
\end{tabular}

** Significant at $P<0.01$.

${ }^{a}$ Lodging score: 0 (no lodging) -4 (completely lodged).

${ }^{b}$ ns, non-significant at $P<0.05$.

Table 2. Correlation coefficients between lodging scores of RILs in each pair of years

\begin{tabular}{lcccc}
\hline \hline & 2008 & 2009 & 2011 & 2012 \\
\hline 2008 & - & $0.461 * * *$ & $0.340 * * *$ & $0.424 * * *$ \\
2009 & $0.461 * * *$ & - & $0.440 * * *$ & $0.268 * * *$ \\
2011 & $0.340 * * *$ & $0.440 * * *$ & - & $0.390 * * *$ \\
2012 & $0.424 * * *$ & $0.268 * * *$ & $0.390 * * *$ & - \\
\hline
\end{tabular}

*** Significant at $P<0.001$.

qLS19-1 and qLS13-1, were detected on chromosome-19 (Chr-19) (MLG-L) and Chr-13 (MLG-F), respectively (Table 3). The $q L S 19-1$ and $q L S 13-1$ loci had LOD scores of 11.4 and 3.7, respectively (Table 3 ). The $\mathrm{TH}$ allele at qLS19-1 promoted a stronger LT (Table 3). The LOD score peak of $q L S 19-1$ was located at Sat_099 (Fig. 3A). The LOD score peak of $q L S 13-1$ was located in the region

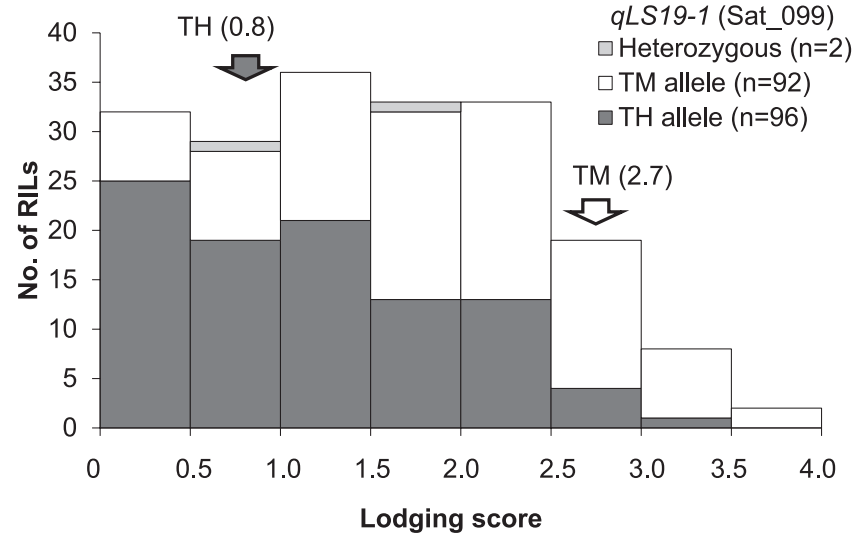

Fig. 2. Frequency distribution of the average lodging score over four years in the RILs. The lodging scores (LSs) of Toyoharuka (TH) and Toyomusume (TM) are shown in parentheses using a LS scale of 0 (no lodging)-4 (completely lodged). 
between Satt334 and Sat 313 (Fig. 3B). The nearest marker to $q$ LS13-1 was Sat_313 (Table 3).

The LSs of the RILs with TH alleles at Sat 099 were significantly lower than the TM alleles in each year $(P<0.01$, Table 4$)$. The main stem lengths of the RILs with TH alleles at Sat 099 were similar to those of the TM alleles in 2008 and 2012 (Table 4). The seed yields of the RILs with TH alleles at Sat_099 were similar to those of the TM alleles in each year (Table 4). These results indicated that $q L S 19-1$ was a stable QTL, and rarely had a negative influence on seed yield.

In contrast, the TM allele at Sat_313 contributed stronger tolerance (Table 3). The LSs of the RILs with TM alleles at Sat 313 were lower than those with TH alleles in 2012 $(P<0.05$, Table 5$)$. The main stem lengths of the RILs with TM alleles at Sat 313 were shorter than those with TH alleles in each year $(P<0.01$, Table 5). The seed yields of the RILs with TM alleles at Sat_313 were lower than those with TH alleles in 2009 and $2011(P<0.05$, Table 5). These results indicated that $q L S 13-1$ was not a stable QTL, and frequently had a negative influence on seed yield.

QTL analysis for LS was also performed each year. However, no significant QTLs were detected (data not shown).

\section{Evaluation of LT in NILs}

As it was a major and stable QTL, further study focused on the qLS19-1 locus (Tables 3, 4). NILs were developed from RILs heterozygous at Sat_099, the nearest marker to qLS19-1. The LS of NIL-TH was lower than that of NILTM $(P<0.05$; Table 6). The 100 -seed weight of NIL-TH
Table 3. QTL analysis of lodging score (four year average)

\begin{tabular}{lcccccc}
\hline \hline $\begin{array}{l}\text { Chr } \\
(\mathrm{LG})^{a}\end{array}$ & $\begin{array}{c}\text { Position } \\
(\mathrm{cM})\end{array}$ & $\begin{array}{c}\text { Nearest } \\
\text { marker }\end{array}$ & LOD $^{b}$ & $\begin{array}{c}\mathrm{R}^{2} \\
(\%)^{c}\end{array}$ & $\begin{array}{c}\text { Additive } \\
\text { effect }^{d}\end{array}$ & $\begin{array}{c}\text { QTL } \\
\text { name }\end{array}$ \\
\hline $19(\mathrm{~L})$ & 110.9 & Sat_099 & 11.4 & 19.8 & -0.40 & $q L S 19-1$ \\
$13(\mathrm{~F})$ & 123.3 & Sat_313 & 3.7 & 10.9 & 0.29 & $q L S 13-1$ \\
\hline
\end{tabular}

${ }^{a} \mathrm{Chr}$, chromosome; LG, linkage group.

${ }^{b}$ LOD, logarithm of odds determined by composite interval mapping; The threshold LOD value at $5 \%$ probability level was calculated by a thousand-replicate permutation test. The value was 3.5.

${ }^{c}$ Percentage phenotypic variance explained by the QTL.

${ }^{d}$ The effect of the TH allele on the QTL. Lodging score: 0 (no lodging)-4 (completely lodged).

was heavier than that of NIL-TM $(P<0.05$; Table 6$)$. The other agronomic traits: flowering date, maturing date, main stem lengths, number of main stem nodes, number of branches, and seed yield were similar in NIL-TH and NILTM (Table 6). These results suggested that the TH allele at the Sat 099 locus promoted a stronger LT, and rarely had a negative influence on seed yield in the NILs.

\section{Evaluation of LT in backcrossed lines}

The $\mathrm{BC}_{2}$ lines were developed by MAS for $q L S 19-1$. TMBC2-2 was lodging tolerant while TM, a backcrossed parent, had high lodging at the young pod to maturing stage (Fig. 1C, 1D). The LSs of TMBC2-1 and TMBC2-2 were lower than in TM $(P<0.05$; Table 7$)$. The maturing times of TMBC2-1 and TMBC2-2 were 2-4 days shorter than observed in TM (Table 7). This may be because TM had severe lodging (Table 7) and a later maturing date. The main
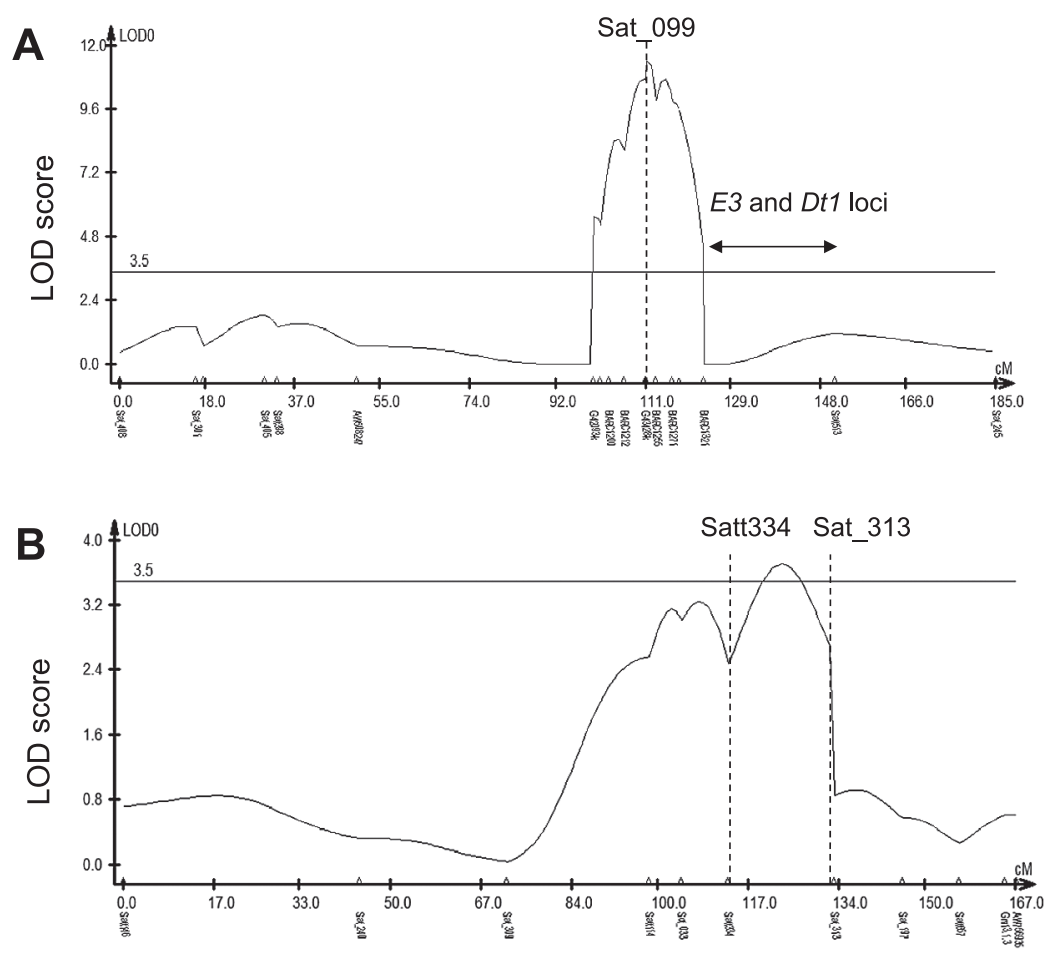

Fig. 3. LOD score plot of QTLs associated with lodging score in the RILs. (A) $q L S 19-1$ located on Chr-19. (B) $q L S 13-1$ located on Chr-13. The LOD threshold value at the $5 \%$ probability level was 3.5. Arrows show the location of the E3 and Dt1 loci. 
Table 4. Relationship between the marker genotype at $q L S 19-1$ and agronomic traits in the RILs

\begin{tabular}{|c|c|c|c|c|c|c|}
\hline Year & $\begin{array}{l}\text { Generation } \\
\text { of RILs }\end{array}$ & $\begin{array}{l}\text { Planting density } \\
\text { (plants } \mathrm{m}^{-2} \text { ) }\end{array}$ & $\begin{array}{c}q L S 19-1 \text { genotype } \\
\text { (Sat_099) }\end{array}$ & $\begin{array}{l}\text { Lodging } \\
\text { score }^{a}\end{array}$ & $\begin{array}{l}\text { Main stem length } \\
(\mathrm{cm})\end{array}$ & 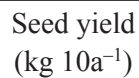 \\
\hline 2008 & $F_{6: 7}$ & 25.0 & $\begin{array}{l}\text { TH } \\
\text { TM }\end{array}$ & $\begin{array}{l}1.6 \\
2.6 \\
* *\end{array}$ & $\begin{array}{l}74 \\
75 \\
\mathrm{~ns}^{b} \\
\end{array}$ & $\begin{array}{l}\mathrm{ND}^{c} \\
\mathrm{ND}\end{array}$ \\
\hline 2009 & $F_{6: 8}$ & 25.0 & $\begin{array}{l}\text { TH } \\
\text { TM }\end{array}$ & $\begin{array}{l}0.3 \\
0.6 \\
* *\end{array}$ & $\begin{array}{l}55 \\
60 \\
* *\end{array}$ & $\begin{array}{c}396 \\
400 \\
\text { ns }\end{array}$ \\
\hline 2011 & $F_{6: 9}$ & 16.7 & $\begin{array}{l}\text { TH } \\
\text { TM }\end{array}$ & $\begin{array}{l}1.3 \\
2.2 \\
* *\end{array}$ & $\begin{array}{l}\text { ND } \\
\text { ND }\end{array}$ & $\begin{array}{c}401 \\
419 \\
\text { ns }\end{array}$ \\
\hline 2012 & $\mathrm{~F}_{6: 10}$ & 16.7 & $\begin{array}{l}\text { TH } \\
\text { TM }\end{array}$ & $\begin{array}{l}1.3 \\
2.0 \\
* *\end{array}$ & $\begin{array}{l}73 \\
73 \\
\text { ns }\end{array}$ & $\begin{array}{c}514 \\
492 \\
\text { ns }\end{array}$ \\
\hline
\end{tabular}

**Significant at $P<0.01$.

${ }^{a}$ Lodging score: 0 (no lodging) -4 (completely lodged).

${ }^{b}$ ns, non-significant at $P<0.05$.

${ }^{c} \mathrm{ND}$, no data.

Table 5. Relationship between the marker genotype at $q L S 13-1$ and agronomic traits in the RILs

\begin{tabular}{|c|c|c|c|c|c|c|}
\hline Year & $\begin{array}{c}\text { Generation } \\
\text { of RILs }\end{array}$ & $\begin{array}{l}\text { Planting density } \\
\text { (plants } \mathrm{m}^{-2} \text { ) }\end{array}$ & $\begin{array}{c}q L S 13-1 \text { genotype } \\
\text { (Sat_313) }\end{array}$ & $\begin{array}{c}\text { Lodging } \\
\text { score }^{a}\end{array}$ & $\begin{array}{l}\text { Main stem length } \\
(\mathrm{cm})\end{array}$ & $\begin{array}{l}\text { Seed yield } \\
\left(\mathrm{kg} 10 \mathrm{a}^{-1}\right)\end{array}$ \\
\hline 2008 & $\mathrm{~F}_{6: 7}$ & 25.0 & $\begin{array}{l}\text { TH } \\
\text { TM }\end{array}$ & $\begin{array}{c}2.4 \\
2.0 \\
\mathrm{~ns}^{b}\end{array}$ & $\begin{array}{l}77 \\
73 \\
* * \\
\end{array}$ & $\begin{array}{l}\mathrm{ND}^{c} \\
\mathrm{ND}\end{array}$ \\
\hline 2009 & $F_{6: 8}$ & 25.0 & $\begin{array}{l}\mathrm{TH} \\
\mathrm{TM}\end{array}$ & $\begin{array}{l}0.5 \\
0.4 \\
\text { ns }\end{array}$ & $\begin{array}{l}60 \\
56 \\
* *\end{array}$ & $\begin{array}{c}418 \\
390 \\
*\end{array}$ \\
\hline 2011 & $F_{6: 9}$ & 16.7 & $\begin{array}{l}\text { TH } \\
\text { TM }\end{array}$ & $\begin{array}{l}1.8 \\
1.6 \\
\mathrm{~ns} \\
\end{array}$ & $\begin{array}{l}\text { ND } \\
\text { ND }\end{array}$ & $\begin{array}{c}424 \\
401 \\
* \\
\end{array}$ \\
\hline 2012 & $F_{6: 10}$ & 16.7 & $\begin{array}{l}\mathrm{TH} \\
\mathrm{TM}\end{array}$ & $\begin{array}{l}1.8 \\
1.4 \\
*\end{array}$ & $\begin{array}{l}76 \\
71 \\
* *\end{array}$ & $\begin{array}{c}493 \\
521 \\
\text { ns }\end{array}$ \\
\hline
\end{tabular}

*** Significant at $P<0.05$ and $P<0.01$, respectively.

${ }^{a}$ Lodging score: 0 (no lodging) -4 (completely lodged).

${ }^{b}$ ns, non-significant at $P<0.05$.

${ }^{c} \mathrm{ND}$, no data.

Table 6. Relationship between the marker genotype at $q L S 19-1$ and agronomic traits in the NILs (25.0 plants $\mathrm{m}^{-2}$; average in 2010 and 2011)

\begin{tabular}{|c|c|c|c|c|c|c|c|c|c|}
\hline $\begin{array}{l}\text { Cultivar } \\
\text { or line }\end{array}$ & $\begin{array}{l}q L S 19-1 \\
\text { genotype } \\
\text { (Sat_099) }\end{array}$ & $\begin{array}{l}\text { Lodging } \\
\text { score }^{a}\end{array}$ & $\begin{array}{c}\text { Flowering } \\
\text { time (days) }\end{array}$ & $\begin{array}{l}\text { Maturing } \\
\text { time (days) }\end{array}$ & $\begin{array}{l}\text { Main stem } \\
\text { length }(\mathrm{cm})\end{array}$ & $\begin{array}{l}\text { No. of main } \\
\text { stem nodes }\end{array}$ & $\begin{array}{c}\text { No. of } \\
\text { branches } \\
\left(\text { plant }^{-1}\right)\end{array}$ & $\begin{array}{l}\text { Seed yield } \\
\left(\mathrm{kg} 10 \mathrm{a}^{-1}\right)\end{array}$ & $\begin{array}{c}100 \text {-seed } \\
\text { weight }(\mathrm{g})\end{array}$ \\
\hline $\mathrm{TH}$ & $\mathrm{TH}$ & $0.7 \mathrm{~d}^{b}$ & $57 \mathrm{a}$ & $133 \mathrm{a}$ & $68 \mathrm{a}$ & $10.1 \mathrm{a}$ & $0.9 \mathrm{c}$ & $393 \mathrm{~b}$ & $38.2 \mathrm{c}$ \\
\hline TM & $\mathrm{TM}$ & $2.6 \mathrm{a}$ & $57 \mathrm{a}$ & $136 \mathrm{a}$ & $71 \mathrm{a}$ & $10.1 \mathrm{a}$ & $2.0 \mathrm{a}$ & $431 \mathrm{ab}$ & $38.6 \mathrm{c}$ \\
\hline NIL-TH & $\mathrm{TH}$ & $1.3 \mathrm{c}$ & $56 \mathrm{a}$ & $131 \mathrm{a}$ & $68 \mathrm{a}$ & $9.9 \mathrm{a}$ & $1.5 \mathrm{~b}$ & $427 \mathrm{ab}$ & $43.0 \mathrm{a}$ \\
\hline NIL-TM & TM & $1.9 \mathrm{~b}$ & $55 \mathrm{a}$ & $131 \mathrm{a}$ & $66 \mathrm{a}$ & $9.9 \mathrm{a}$ & $1.9 \mathrm{ab}$ & $443 \mathrm{a}$ & $40.7 \mathrm{~b}$ \\
\hline
\end{tabular}

${ }^{a}$ Lodging score: 0 (no lodging)-4 (completely lodged).

${ }^{b}$ Values within a trait with the same letters were not significantly different at $P<0.05$ (Tukey-Kramer multiple comparison test).

stem length of TMBC2-1 was shorter than seen in TM (Table 7). The 100-seed weight of TMBC2-1 was heavier than that of TM $(P<0.05$; Table 7). Other agronomic traits, including flowering date, number of branches, and seed yield were similar in TMBC2-1, TMBC2-2, and TM (Table 7). These results suggested that the TH allele at Sat_099 promoted stronger LT, and rarely had a negative influence on seed yield in the BC lines.

\section{MAS for qLS19-1 in the T248 $\times$ TH background}

We developed breeding lines by MAS for $q L S 19-1$ from a T248 $\times$ TH cross to investigate the effects of $q L S 19-1$ in a different background. According to the marker genotypes, the genotype at the $E 1$ to $E 4$ loci of T248 was estimated as ele2E3e4. T248 was determinate (dt1 genotype). The frequency distribution of LS in the $\mathrm{F}_{3}$ lines is shown in Fig. 4. The average LSs of lines with the TH allele were lower than 
Table 7. Relationship between the marker genotype at $q L S 19-1$ and agronomic traits in the backcrossed lines (16.7 plants $\mathrm{m}^{-2}$; average in 2012 and 2013)

\begin{tabular}{|c|c|c|c|c|c|c|c|c|c|}
\hline $\begin{array}{l}\text { Cultivar } \\
\text { or line }\end{array}$ & $\begin{array}{l}\text { qLS19-1 } \\
\text { genotype } \\
\text { (Sat_099) }\end{array}$ & $\begin{array}{l}\text { Lodging } \\
\text { score }^{a}\end{array}$ & $\begin{array}{c}\text { Flowering } \\
\text { time (days) }\end{array}$ & $\begin{array}{l}\text { Maturing } \\
\text { time (days) }\end{array}$ & $\begin{array}{l}\text { Main stem } \\
\text { length }(\mathrm{cm})\end{array}$ & $\begin{array}{l}\text { No. of main } \\
\text { stem nodes }\end{array}$ & $\begin{array}{l}\text { No. of } \\
\text { branches } \\
\left(\text { plant }^{-1}\right)\end{array}$ & $\begin{array}{l}\text { Seed yield } \\
\left(\mathrm{kg} 10 \mathrm{a}^{-1}\right)\end{array}$ & $\begin{array}{c}\text { 100-seed } \\
\text { weight }(\mathrm{g})\end{array}$ \\
\hline $\mathrm{TH}$ & $\mathrm{TH}$ & $2.0 \mathrm{~b}^{b}$ & $55 \mathrm{a}$ & $130 \mathrm{~b}$ & $82 \mathrm{a}$ & $11.5 \mathrm{a}$ & $1.6 \mathrm{~b}$ & $407 \mathrm{a}$ & $43.0 \mathrm{~b}$ \\
\hline $\mathrm{TM}$ & TM & $3.6 \mathrm{a}$ & $54 \mathrm{a}$ & $135 \mathrm{a}$ & $78 \mathrm{ab}$ & $10.6 \mathrm{~b}$ & $2.8 \mathrm{a}$ & $338 \mathrm{~b}$ & $43.1 \mathrm{~b}$ \\
\hline TMBC2-1 & $\mathrm{TH}$ & $1.7 \mathrm{~b}$ & $54 \mathrm{a}$ & $133 \mathrm{ab}$ & $69 \mathrm{c}$ & $9.8 \mathrm{c}$ & $2.3 \mathrm{a}$ & $349 \mathrm{~b}$ & $47.5 \mathrm{a}$ \\
\hline TMBC2-2 & $\mathrm{TH}$ & $1.3 \mathrm{~b}$ & $54 \mathrm{a}$ & $131 \mathrm{~b}$ & $71 \mathrm{bc}$ & $9.7 \mathrm{c}$ & $2.3 \mathrm{a}$ & $380 \mathrm{ab}$ & $42.7 \mathrm{~b}$ \\
\hline
\end{tabular}

${ }^{a}$ Lodging score: 0 (no lodging)-4 (completely lodged).

${ }^{b}$ Values within a trait with the same letters were not significantly different at $P<0.05$ (Tukey-Kramer multiple comparison test).

those with the T248 allele $(P<0.01)$. In 2012, eight breeding lines with the TH allele at Sat 099 were tested. The LSs of the six lines were significantly lower than in T248 (Table 8). We obtained three breeding lines, 2129-2, 5, and 7 ; in these the LSs were significantly lower, and the yield significantly greater, than that of T248 (Table 8). The maturing times of 2129-2, 5, and 7 were 5 days shorter than observed in T248 (Table 8). This may be because T248 had severe lodging (Table 8) and a later maturing date.

\section{Discussion}

In previous studies, QTLs for LS frequently influenced other agronomic traits, such as flowering date, plant height, and determinate habit (Lee et al. 1996, Mansur et al. 1993, Orf et al. 1999, Specht et al. 2001). In this study, the qLS131 was not stable, and frequently had a negative influence on seed yield (Table 5). Matsukawa and Banba (1986) reported a positive correlation between main stem length and LS. The main stem lengths of RILs with TM alleles at Sat_313 were shorter than those with $\mathrm{TH}$ alleles in each year (Table 5). In fact, a QTL for main stem length was detected in the proximal region of $q L S 13-1$ (data not shown). Therefore, we speculate that $q L S 13-1$ may be a QTL for main stem length. In contrast, $q L S 19-1$ was identified as a stable QTL, and rarely had a negative influence on seed yield or other agronomic traits (Tables 3, 4, 6, 7). No QTLs for main stem length were detected in the proximal region of qLS191 (data not shown). The MAS of $q L S 19-1$ was also effective

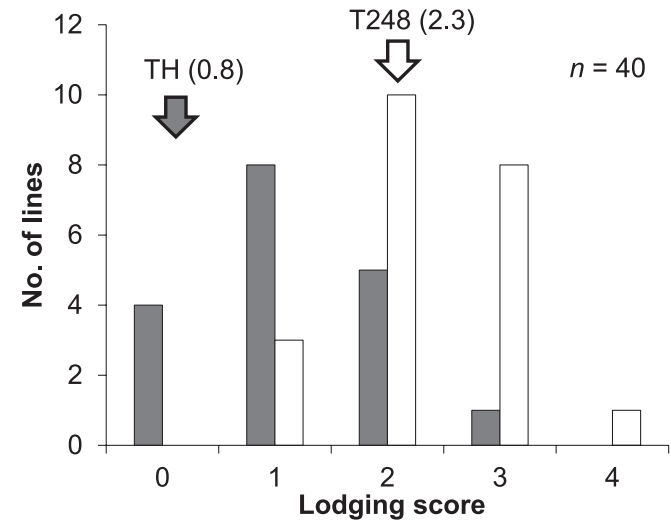

Fig. 4. The effect of $q L S 19-1$ on lodging tolerance in the Toiku 248 background. Frequency distribution of the lodging score (LS) in $\mathrm{F}_{3}$ lines derived from a Toiku $248(\mathrm{~T} 248) \times$ Toyoharuka $(\mathrm{TH})$ cross in 2011. LSs of the parental lines are shown in parentheses. LS scale: 0 (no lodging)-4 (completely lodged). The average LS of lines with either TH or T248 alleles was 1.3 or 2.3 , respectively $(P<0.01)$. Shaded bars: lines with the TH allele at Sat_099 $(n=18)$. White bars: lines with the T248 allele at Sat_099 $(n=22)$. The plant population density was 25.0 plants $\mathrm{m}^{-2}$.

in the T248 $\times$ TH background (Fig. 4, Table 8). These results suggest that MAS for $q L S 19-1$ will be of great use for improving LT in breeding programs.

Combine-harvesting loss through lodging of soybeans is estimated to be about 20\% (Uchikawa et al. 2006). In this study, seed yield was determined by hand-harvesting. The

Table 8. Agronomic traits of the $\mathrm{F}_{4}$ lines derived from the Toiku $248(\mathrm{~T} 248) \times$ Toyoharuka $(\mathrm{TH})$ cross $\left(16.7\right.$ plants $\left.^{-2} ; 2012\right)$

\begin{tabular}{|c|c|c|c|c|c|c|}
\hline $\begin{array}{l}\text { Cultivar } \\
\text { or line }\end{array}$ & $\begin{array}{c}q L S 19-1 \text { genotype } \\
\text { (Sat_099) }\end{array}$ & Lodging score ${ }^{a}$ & $\begin{array}{c}\text { Flowering time } \\
\text { (days) }\end{array}$ & $\begin{array}{l}\text { Maturing time } \\
\text { (days) }\end{array}$ & $\begin{array}{l}\text { Main stem length } \\
(\mathrm{cm})\end{array}$ & $\begin{array}{l}\text { Seed yield } \\
\left(\mathrm{kg} 10 \mathrm{a}^{-1}\right)\end{array}$ \\
\hline $\mathrm{T} 248$ & $\mathrm{~T} 248$ & 4.0 & 65 & 140 & 82 & 348 \\
\hline $\mathrm{TH}$ & $\mathrm{TH}$ & $1.8^{*}$ & $62 * *$ & 137 & 77 & $473^{*}$ \\
\hline $2129-1$ & $\mathrm{TH}$ & $1.8^{*}$ & $62 * *$ & $136^{*}$ & 78 & 451 \\
\hline $2129-2$ & TH & $1.8^{*}$ & $60 * *$ & $135^{*}$ & $90^{*}$ & $465^{*}$ \\
\hline $2129-3$ & TH & 2.8 & $63^{*}$ & 136 & 85 & $489^{*}$ \\
\hline $2129-4$ & $\mathrm{TH}$ & $1.0 * *$ & $62 * *$ & 136 & 76 & 444 \\
\hline $2129-5$ & $\mathrm{TH}$ & $1.5^{*}$ & $61 * *$ & $135^{*}$ & $72 * *$ & $485 *$ \\
\hline $2129-6$ & TH & 2.8 & 64 & 138 & 88 & 450 \\
\hline $2129-7$ & $\mathrm{TH}$ & $2.0^{*}$ & 65 & $135^{*}$ & $91 * *$ & $476^{*}$ \\
\hline $2129-8$ & TH & $1.8^{*}$ & 64 & $134 * *$ & 79 & 435 \\
\hline
\end{tabular}

${ }^{a}$ Lodging score: 0 (no lodging) -4 (completely lodged).

*,** Significant at $P<0.05$ and $P<0.01$, respectively. Dunnett's test was performed for each agronomic trait using T248 as the reference. 
seed yields were similar in TM and TMBC lines (Table 7). We speculate that the combine-harvesting loss of TM might be greater than that of TMBC lines because TM had severe lodging (Table 7, Fig. 1D). In the future, combineharvesting tests will be required to clarify whether TMBC lines yields more than TM or not.

The TH allele at Sat 099 promoted a heavier seed. The 100-seed weights of NIL-TH and TMBC2-1 were heavier than those of NIL-TM and TM, respectively (Tables 6, 7). We could not confirm whether a difference in the 100-seed weight was caused by the other gene linked to qLS19-1 or by pleiotropism of $q L S 19-1$. In either case, heavier seeds are preferred for boiled-bean processing in Japan (Kato et al. 2014, Tanaka 2011). Therefore, we feel that the effect of the TH allele at Sat 099 on the 100-seed weight is not disadvantageous for breeding programs in Japan.

The number and distribution of branches in soybean effects LT (Sayama et al. 2010). The number of branches in TH was significantly less than in TM (Tables 3, 6, 7). However, the number of branches in the NIL-TH and BC lines was similar to that of NIL-TM and TM, respectively (Tables 6, 7). The number of branches in the BC lines was significantly greater than in $\mathrm{TH}$ although $\mathrm{LT}$ in the $\mathrm{BC}$ lines was comparable to that in TH (Table 7). Therefore, the effect of qLS19-1 could not be explained by the number of branches alone. Saito et al. (2012) reported that the number of branches was higher, and that branches compensated seed yield when plants lodged at the flowering stage. In this study, the number of branches was only measured at the maturing stage. Therefore, it will be important to investigate the number of branches after the flowering stage to clarify the relation between LT in TH and the number of branches.

The agronomic traits of TMBC2-1 and TMBC2-2 were slightly different (Table 7). It is possible that another genomic region might influence main stem length or number of main stem nodes in the BC lines. To confirm the effect of qLS19-1 more accurately, it will be important to develop NILs from TMBC lines with more BCs to TM.

The candidate genes of $E 3$ and $D t 1$ have been reported and are considered to be linked (Liu et al. 2010, Watanabe et al. 2009). Previous studies reported that QTLs for LS were located in the E3 and Dt1 locus on Chr-19 (Lee et al. 1996, Mansur et al. 1993, Orf et al. 1999, Specht et al. 2001). These QTLs are recorded as Ldge 1-1, 4-2, 4-3, 8-4, and 9-5 in SoyBase (www.soybase.org). Moreover, the QTLs for traits associated with lodging, branch number, or max internode length also located to the proximal region of the E3 and Dt1 loci (Liu et al. 2007, Sayama et al. 2010). However, it was not determined whether genes responsible for these QTLs are closely linked to $E 3$ and $D t 1$ or the pleiotropism of them. In this study, qLS19-1 was located in the proximal region of E3 and Dt1 (Table 3, Fig. 3A). However, the LOD score peak of $q L S 19-1$ was located in the region upstream of $E 3$ and Dt1 on Chr-19 (Fig. 3A), and the genotypes of the cultivars and breeding lines used in this study were $E 3$ and $d t 1$ (Table 1). Therefore, the gene responsible for $q L S 19-1$ is unlikely to be either E3 or Dt1.

There have been numerous reports on QTLs associated with LT. Kashiwagi and Ishimaru (2004) identified a QTL for pushing resistance of the lower part in rice. Ookawa et al. (2010) identified an effective QTL, and isolated the candidate gene for culm strength in rice. In soybean, Chen et al. (2011) reported QTLs associated with stem strength, and Sayama et al. (2010) identified QTLs for branch number. In this study, other QTLs may also be involved, as the distribution of LSs could not be explained by qLS19-1 alone (Fig. 2). To detect these other QTLs, it might prove effective to perform QTL analysis using the traits associated with LT.

In summary, we identified a stable QTL for LT. The TH allele at Sat 099 rarely had a negative influence on seed yield or other agronomic traits in both NILs and BC lines. Moreover, the TH allele at Sat_099 promoted a stronger LT in the T248 $\times$ TH background. Our results suggest that MAS for $q L S 19-1$ is effective for improving LT in breeding programs.

\section{Acknowledgements}

We are grateful to Seiji Hagihara, Chika Suzuki, Satoshi Kobayashi and Hiroshi Shinada, Hokkaido Research Organization, for providing help with the field tests, and Shin Kato, National Agriculture and Food Research Organization, for advice. This study was supported by a grant from the Ministry of Agriculture, Forestry, and Fisheries of Japan (Genomics for Agricultural Innovation, SOY2002 and DD3140).

\section{Literature Cited}

Bernard, R.L. (1972) Two genes affecting stem termination in soybeans. Crop Sci. 12: 235-239.

Chen,H., Z.Shan, A.Sha, B.Wu, Z.Yang, S.Chen, R.Zhou and X.Zhou (2011) Quantitative trait loci analysis of stem strength and related traits in soybean. Euphytica 179: 485-497.

Cober, E.R., J.W. Tanner and H.D. Voldeng (1996) Genetic control of photoperiod response in early-maturing near-isogenic soybean lines. Crop Sci. 36: 601-605.

Cober,E.R. and M.J.Morrison (2010) Regulation of seed yield and agronomic characters by photoperiod sensitivity and growth habit genes in soybean. Theor. Appl. Genet. 120: 1005-1012.

Foley, T.C., J.H. Orf and J.W.Lambert (1986) Performance of related determinate and indeterminate soybean isolines. Crop Sci. 26: 5-8.

Hwang, T.Y., T. Sayama, M.Takahashi, Y.Takada, Y.Nakamoto, H. Funatsuki, H. Hisano, S. Sasamoto, S. Sato, S. Tabata et al. (2009) High-density integrated linkage map based on SSR markers in soybean. DNA Res. 16: 213-225.

Ikeda, T., S. Onishi, M. Senda, T. Miyoshi, M. Ishimoto, K. Kitamura and H. Funatsuki (2009) A novel major quantitative trait locus controlling seed development at low temperature in soybean (Glycine max). Theor. Appl. Genet. 118: 1477-1488.

Kashiwagi,T. and K. Ishimaru (2004) Identification and functional analysis of a locus for improvement of lodging resistance in rice. Plant Physiol. 134: 676-683.

Kato, S., T. Sayama, K. Fujii, S. Yumoto, Y.Kono, T.Y.Hwang, A. 
Kikuchi, Y.Takada, Y.Tanaka, T. Shiraiwa et al. (2014) A major and stable QTL associated with seed weight in soybean across multiple environments and genetic backgrounds. Theor. Appl. Genet. 127: 1365-1374.

Lee, S.H., M.A. Bailey, M.A.R.Mian, E.R. Shipe, D.A.Ashley, W.A. Parrott, R.S. Hussey and H.R. Boerma (1996) Identification of quantitative trait loci for plant height, lodging, and maturity in a soybean population segregating for growth habit. Theor. Appl. Genet. 92: 516-523.

Lincoln, S.E., M.J.Daly and E.S.Lander (1993) MAPMAKER/EXP. Whitehead Institute of Biomedical Research, Cambridge, MA.

Liu, B., T. Fujita, Z.H. Yan, S. Sakamoto, D. Xu and J.Abe (2007) QTL mapping of domestication-related traits in soybean (Glycine max). Ann. Bot. 100: 1027-1038.

Liu, B., A. Kanazawa, H. Matsumura, R. Takahashi, K. Harada and J.Abe (2008) Genetic redundancy in soybean photoresponses associated with duplication of phytochrome A gene. Genetics 180: 995-1007.

Liu, B., S. Watanabe, T.Uchiyama, F.Kong, A. Kanazawa, Z.Xia, A. Nagamatsu, M.Arai, T. Yamada, K. Kitamura et al. (2010) The soybean stem growth habit gene Dt1 is an ortholog of Arabidopsis TERMINAL FLOWER1. Plant Physiol. 153: 198-210.

Mansur,L.M., K.G.Lark, H.Kross and A.Oliveira (1993) Interval mapping of quantitative trait loci for reproductive, morphological, and seed traits of soybean (Glycine max L.). Theor. Appl. Genet. 86: 907-913.

Matsukawa, I. and H. Banba (1986) The lodging response of soybeans to different manuring and plant density. Rep. Hokkaido Br., Crop Sci. Soc. Jpn and Hokkaido Br., Jpn. Soc. Breeding 26: 2.

Noor, R.B.M. and C.E. Caviness (1980) Influence of lodging on pod distribution and seed yield in soybeans. Agron. J. 72: 904-906.

Ohnishi, S., H. Funatsuki, A. Kasai, T. Kurauchi, N.Yamaguchi, T. Takeuchi, H. Yamazaki, H. Kurosaki, S. Shirai, T. Miyoshi et al. (2011) Variation of GmIRCHS (Glycine max inverted-repeat CHS pseudogene) is related to tolerance of low temperature-induced seed coat discoloration in yellow soybean. Theor. Appl. Genet. 122: 633-642.

Ono, M., T.Kanamaru, Y.Ohga and H.Fujii (1990) The growth and adaptability for the multi-purpose combine harvesting in the level row and non-ridging culture of soybean plant. Rep. Kyushu Br. Crop Sci. Soc. Jpn. 57: 37-39.

Ookawa, T., T. Hobo, M. Yano, K. Murata, T.Ando, H. Miura, K.Asano, Y.Ochiai, M.Ikeda, R. Nishitani et al. (2010) New approach for rice improvement using a pleiotropic QTL gene for lodging resistance and yield. Nat. Commun. 1: 132. doi: 10.1038/ncomms1132.

Orf, J.H., K. Chase, T. Jarvik, L.M. Mansur, P.B. Cregan, F.R.Adler and K.G. Lark (1999) Genetics of soybean agronomic traits: I. Comparison of three related recombinant inbred populations. Crop Sci. 39: $1642-1651$.

Saito, K., K. Nishimura and T.Kitahara (2012) Effect on lodging on seed yield of field-grown soybean — artificial lodging and lodging preventing treatments-. Jpn. J. Crop Sci. 81: 27-32.

Sasaki, K., K. Sunada, T. Tsuchiya, S.Sakai, M.Kamiya, T.Ito and T. Sanbuichi (1988) A new soybean variety 'Toyomusume'. Bull. Hokkaido Pref. Agric. Exp. Stn. 57: 1-12.

Sayama, T., T.Y.Hwang, H.Yamazaki, N.Yamaguchi, K.Komatsu, M. Takahashi, C. Suzuki, T. Miyoshi, Y. Tanaka, Z. Xia et al. (2010) Mapping and comparison of quantitative trait loci for soybean branching phenotype in two locations. Breed. Sci. 60: 380-389.

Sayama, T., T.Y.Hwang, K. Komatsu, Y. Takada, M. Takahashi, S. Kato,
H. Sasama, A. Higashi, Y. Nakamoto, H. Funatsuki et al. (2011) Development and application of a whole-genome simple sequence repeat panel for high-throughput genotyping in soybean. DNA Res. 18: 107-115.

Song, Q., G. Jia, Y.Zhu, D. Grant, R.T.Nelson, E.Y.Hwang, D.L. Hyten and P.B. Cregan (2010) Abundance of SSR motifs and development of candidate polymorphic SSR markers (BARCSOYSSR_1.0) in soybean. Crop Sci. 50: 1950-1960.

Specht, J.E., K.Chase, M. Macrander, G.L.Graef, J.Chung, J.P. Markwell, M.Germann, J.H. Orf and K.G.Lark (2001) Soybean response to water: A QTL analysis of drought tolerance. Crop Sci. 41: 493-509.

Tanaka, Y., S. Shirai, S. Yumoto, I. Matsukawa, S. Hagihara, H. Yamazaki, C. Suzuki, S.Ohnishi, H.Kurosaki and M.Tsunoda (2009) New soybean variety Toyoharuka with tolerance to cool weather, resistance to seed discoloration, and high adaptability for combine harvest in dense planting. Breed. Res. 11 (Suppl. 2) 128.

Tanaka,Y. (2011) Breeding of legume crops for high quality in Hokkaido: part 2. Legume Newsletter 62: 23-30.

Tuinstra, M.R., G.Ejeta and P.B.Goldsbrough (1997) Heterogeneous inbred family (HIF) analysis: a method for developing nearisogenic lines that differ at quantitative trait loci. Theor. Appl. Genet. 95: 1005-1011.

Uchikawa, O., M. Miyazaki and K. Tanaka (2006) The relationship lodging of soybean and the combine harvesting loss in Fukuoka Prefecture in 2004. Rep. Kyushu Br. Crop Sci. Soc. Jpn. 72: 32-34.

Wang, S., C.J.Basten and Z.B.Zeng (2007) Windows QTL Cartographer 2.5. Department of Statistics, North Carolina State University, Raleigh, NC. http: //statgen.ncsu.edu/qtlcart/WQTLCart.htm

Watanabe, S., R. Hideshima, Z.Xia, Y.Tsubokura, S. Sato, Y. Nakamoto, N. Yamanaka, R. Takahashi, M. Ishimoto, T. Anai et al. (2009) Map-based cloning of the gene associated with the soybean maturity locus E3. Genetics 182: 1251-1262.

Watanabe, S., Z.Xia, R. Hideshima, Y.Tsubokura, S. Sato, N. Yamanaka, R. Takahashi, T.Anai, S. Tabata, K. Kitamura et al. (2011) A map-based cloning strategy employing a residual heterozygous line reveals that the GIGANTEA gene is involved in soybean maturity and flowering. Genetics 188: 395-407.

Weber, C.R. and W.R. Fehr (1966) Seed yield losses from lodging and combine harvesting in soybeans. Agron. J. 58: 287-289.

Woods, S.J. and M.L. Swearingin (1977) Influence of simulated early lodging upon soybean seed yield and its component. Agron. J. 69: 239-242.

Xia, Z., S. Watanabe, T. Yamada, Y. Tsubokura, H. Nakashima, H.Zhai, T.Anai, S. Sato, T. Yamazaki, S. Lü et al. (2012) Positional cloning and characterization reveal the molecular basis for soybean maturity locus E1 that regulates photoperiodic flowering. Proc. Natl. Acad. Sci. USA 109: 2155-2164.

Yamanaka, N., S.Ninomiya, M.Hoshi, Y.Tsubokura, M. Yano, Y. Nagamura, T. Sasaki and K. Harada (2001) An informative linkage map of soybean reveals QTLs for flowering time, leaflet morphology and regions of segregation distortion. DNA Res. 8: 61-72.

Yamanaka, N., S. Watanabe, K.Toda, M.Hayashi, H.Fuchigami, R. Takahashi and K. Harada (2005) Fine mapping of the FT1 locus for soybean flowering time using a residual heterozygous line derived from a recombinant inbred line. Theor. Appl. Genet. 110: 634-639.

Zeng, Z.B. (1994) Precision mapping of quantitative trait loci. Genetics 136: 1457-1468. 